\title{
Diagnosis of progressive multifocal leucoencephalopathy by hybridisation techniques
}

\author{
R H BOERMAN, ${ }^{\dagger} \dagger$ E P J ARNOLDUS, ${ }^{*}$ A K RAAP, $\dagger$ A C B PETERS, $*$ \\ J TER SCHEGGET, $\ddagger$ M VAN DER PLOEG $\dagger$
}

\section{From the *Department of Neurology, University Hospital, Leiden, the †Department of Cytochemistry and Cytometry, University of Leiden, and the $\ddagger$ Department of Medical Virology, University of Amsterdam, The Netherlands}

SUMMARY In situ hybridisation with acetyl-aminofluorene (AAF) and 35S-labelled DNA probes for polyomaviruses, was used to detect JC virus DNA in brain necropsy material in a patient with progressive multifocal leucoencephalopathy (PML). In a second patient PML was diagnosed from a brain necropsy specimen using the same technique. The main infected cell type were oligodendrocytes; dot hybridisation was used to estimate the number of viral copies in each infected cell. Southern blot hybridisation for further analysis of the viral genome was also carried out.

In situ hybridisation with non-radioactive labelled polyomavirus DNA provides a simple and specific means for studying viral DNA in formaldehyde fixed tissue sections from patients with suspected PML. Even in small biopsy samples hybridisation results can be correlated with standard histopathological, immunocytochemical, and electron microscopic findings.

Progressive multifocal leucoencephalopathy (PML) is a subacute demyelinating disease of the central nervous system, which was first recognised by Astrom et al. ${ }^{1}$ In almost all cases JC virus was found. ${ }^{2-4}$ In two, possibly five patients, a related virus, SV 40 , was identified as the causative agent. ${ }^{5-8}$. As yet, a third polyomavirus, BKV, has not been associated with PML.

PML is thought to be an opportunistic infection developing against a background of impaired immune responses, either iatrogenic or due to other diseases. ${ }^{349}$ It has been recognised, however, in patients without any apparent predisposing factor. ${ }^{34}$ PML is distributed worldwide as is JC virus, and can occur at any age. ${ }^{34}$ Although still distinctly uncommon, susceptible populations will probably increase as a consequence of the extended use of irradiation, immunosuppressive drugs, and the appearance of acquired immune deficiency syndrome (AIDS). ${ }^{10-15}$ As a result, confirmation of this diagnosis before death and investigation of PML is of increasing importance.

The only way to make such an unequivocal diagnosis is by examining biopsy specimens of diseased areas. ${ }^{4}$ The typical neuropathological lesions and the intranuclear polyomavirus virions can be seen by light and electron microscopy, ${ }^{34}$ but these methods are not virus-type specific and electron microscopic evalua- tion is cumbersome. Isolation and cultivation can also be used for virus identification, or for confirmation of the results obtained by other methods. These techniques, however, are difficult to perform, slow, and rather insensitive. ${ }^{4}$ Immunocytochemical and in situ hybridisation techniques permit direct detection of viral antigen and nucleic acids in samples and provide useful and rapid ways of detecting and identifying infected cells. ${ }^{16-24}$ With proper choice of antibodies and nucleic acid probes, both techniques have, in principle, the capacity to distinguish between the different polyomaviruses. ${ }^{19-24} \mathrm{With}$ the advent of non-radioactive labelling techniques for nucleic acids the in situ hybridisation technique is becoming routinely applicable.

We studied the brain tissue of two patients with PML using in situ and filter hybridisation techniques with acetyl aminofluorene (AAF) and radioisotope labelled viral DNA probes. In situ hybridisation was combined with immunocytochemical staining for glial fibrillary acidic protein (GFAP) to characterise the infected cell type, in addition to the use of morphological criteria.

\section{Material and methods}

CASE 1

This patient has been reported elsewhere. ${ }^{13}$ Briefly, a 40 year old man with AIDS and a lung infection 


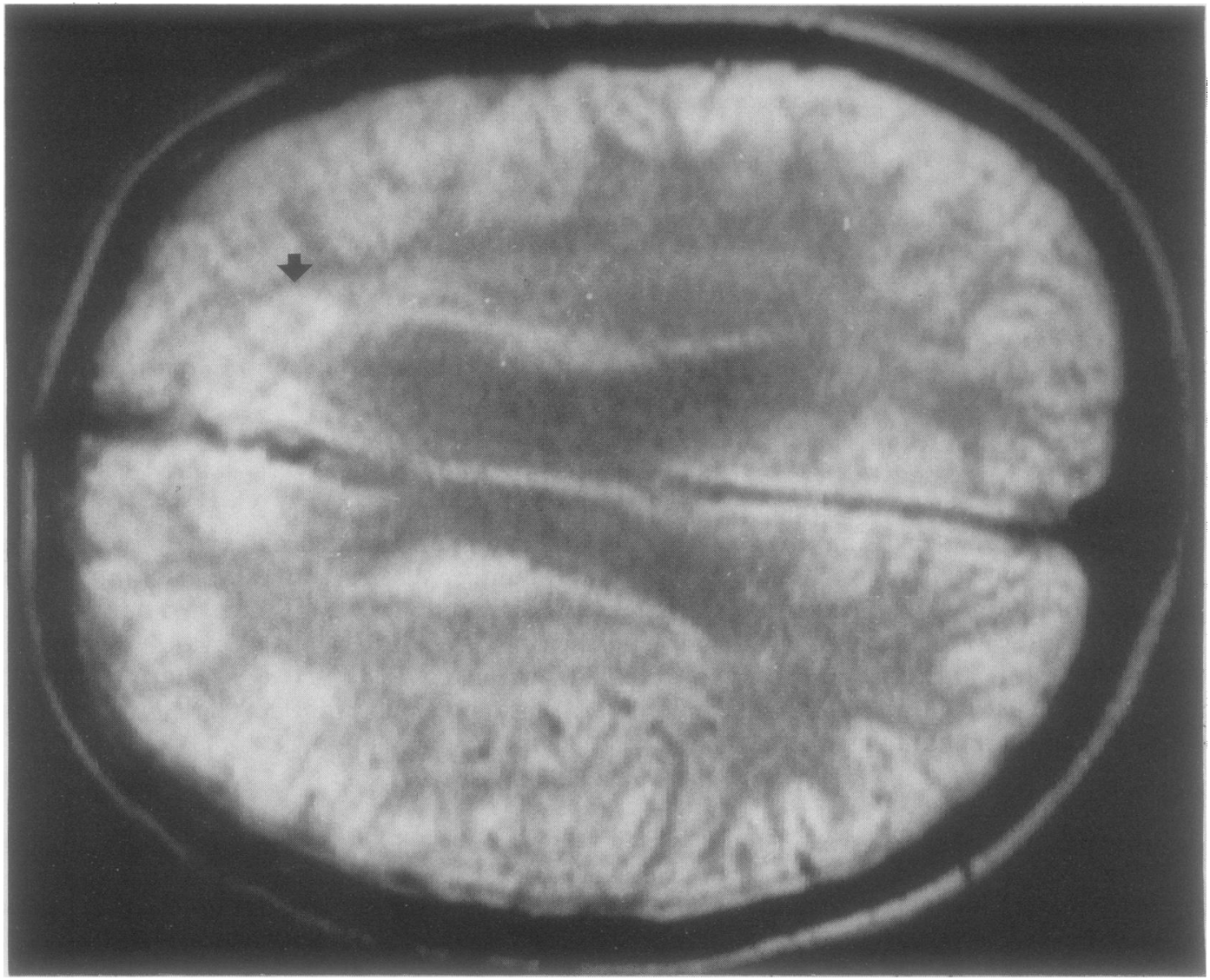

Fig 1 MRI-scan of brain of case 2 showing left frontal lesion (arrow). T2 weighted image, first echo (TR $=2500$ msec, $T E=30 \mathrm{msec}$ ).

caused by Pneumocystic carinii presented with a paresis of the left arm. PML was diagnosed on a brain biopsy specimen both by electron microscopy and detection of JCV-DNA by autoradiographic dothybridisation. Thereafter, his general and neurological condition deteriorated rapidly. The patient died six months after onset of illness. At post mortem examination extensive white matter destruction was found in both hemispheres.

\section{CASE 2}

A 49 year old man with non-Hodgkin's lymphoma of the right lung was diagnosed in January 1986 and treated according to the MACOP-B program. In May 1986 a tuberculosis infection located in the lymphoma was diagnosed and treated with isoniazide, pyrizinamide, and rifampicine. At this time he developed clumsiness of the left hand and over the succeeding six months he developed increasing difficulty in walking and a loss of concentration and memory. Neurological examination in October 1986 showed bradyphrenia, dysarthria, nystagmus on both sides, paresis of the left arm with dysdiadochokinesis and ataxia that was more pronounced on the left side. The MRI-scan showed lesions in the left frontal lobe (fig 1) and in the thalamus on the right side. Biopsy specimens were taken from the left frontal lobe. Microscopic evaluation showed changes compatible with PML with foci of demyelination, loss of oligodendrocytes, large astrocytes and a plasma cell infiltrate. Electron microscopical examination showed many polyoma virions with a diameter of about $40 \mathrm{~nm}$ as well as filamentous forms in a few regressively changed oligodendrocytes. The patient received two courses of treatment with arabinoside-C: day $1,20 \mathrm{mg}$ intrathecally; days 1-6,120 mg intravenously; day 6, $20 \mathrm{mg}$ intrathecally. ${ }^{7}$ His condition improved slightly and remained stable for a few months. In February 1987 the lymphoma in the right lung recurred with an additional localisation of lymphoma in the left lung 
and he received three courses of treatment with mitoxantrone (day $1,12 \mathrm{mg}$ intravenously), VM26 (day $1,100 \mathrm{mg} / \mathrm{m}^{2}$ ) and chlorambucil (days $1-5,20 \mathrm{mg}$ intravenously). His condition did not improve. From July 1987 onwards he progressively deteriorated, in spite of cytostatic treatment. He died at home in February 1988. Necropsy was not performed.

TISSUE PROCESSING AND DNA ISOLATION

For in situ hybridisation frozen brain tissue from case 1 obtained at necropsy was fixed in formaldehyde for 48 hours and embedded in paraffin wax. The period of autolysis of this material is unknown. Biopsy material from case 2 was fixed in formaldehyde and embedded in paraffin wax immediately. Identically treated brain tissue from three patients with herpes simplex type 1 (HSV-1) encephalitis and from one patient with a cerebellar haemorrhage served as negative controls for in situ hybridisation with JC virus probe. For dot-blot and Southern-blot hybridisation, unfixed frozen brain tissue was used, obtained at necropsy from case 1 and at biopsy from case 2 . The tissue was homogenised in a tissue grinder in $1 \mathrm{ml} 50 \mathrm{mM}$ Tris-hydrochloric acid/ $100 \mathrm{mM}$ sodium edetic acid, pH 8.5. Sodium dodecyl sulphate was added to a final concentration of $1 \%$ and the lysate was incubated with pronase $(1 \mathrm{mg} / \mathrm{ml})$ at $50^{\circ} \mathrm{C}$ for two hours. The DNA was extracted twice with phenol saturated with $10 \mathrm{mM}$ Tris-hydrochloric acid ( $\mathrm{pH} 8 \cdot 1)$ and once with chloroform-isoamylalcohol (24:1 v/v). Subsequently, the DNA was precipitated with ethanol, solubilised in $100 \mu 10 \mathrm{mM}$ Tris-hydrochloric acid/1 mM sodium edetic acid, $\mathrm{pH}$ $7 \cdot 5$, and treated with RNase $A(50 \mu \mathrm{g} / \mathrm{ml})$ at $37^{\circ} \mathrm{C}$ for 20 minutes. The phenol was again extracted, precipitated with alcohol, and solubilised in $10 \mathrm{mM}$ Tris-hydrochloric acid/1 mM sodium edetic acid.

\section{PROBES AND LABELLING}

The JCV probe and the BKV probe consisted of total JCV and BKV DNA, respectively, cloned into pBR322. The SV 40 probe was pSVBB37, a recombinant which contains 2.7 kilobase pairs of the SV 40 early coding region (constructed by Dr CJA Sol (Department of Medical Virology, University of Amsterdam)). A mixture of non-overlapping seven genomic cytomegalovirus (CMV) fragments cloned in the single stranded M13 bacteriophage ${ }^{25}$ and pBR322 without insert served as controls. The probes were labelled with AAF to a degree of $5 \%$ modification ${ }^{26}$ and tested by filter hybridisation. AAF-modified probes were considered to be adequately labelled when 1-5 pg could be detected in homologous hybridisation. Probes were radioisotope labelled with $35 \mathrm{~S}$ by nick-translation as previously described. ${ }^{27}$ Specific activities were $1-3 \times 10^{8} \mathrm{dpm} / \mu \mathrm{g}$.

\section{IN SITU HYBRIDISATION}

In situ hyridisation was performed essentially according to the method of Raap et al. ${ }^{25}$ Briefly, $5 \mu \mathrm{m}$ sections were placed on slides pretreated with gelatin-chromealum and glutaraldehyde to prevent loss of tissue adherence. Endogenous peroxidase activity was inactivated for 30 minutes in $1 \% \mathrm{H}_{2} \mathrm{O}_{2}$. Then the sections were incubated with $0-15 \mu \mathrm{g} / \mathrm{ml}$ Proteinase $\mathrm{K}$ (Merck, Darmstadt, West Germany) in $50 \mathrm{mM}$ Tris-hydrochloric acid, $2 \mathrm{mM} \mathrm{CaCl}{ }_{2}\left(\mathrm{pH} \mathrm{7.4)}\right.$ at $37^{\circ} \mathrm{C}$ for 30 minutes. The concentration used depended on the type of tissue. The use of pepsin $(0.4 \mathrm{mg} / \mathrm{ml}$ in $0.2 \mathrm{~N}$ hydrochloric acid) gave better results. ${ }^{28}$ The probe solution, containing $50 \%$ deionised formamide $(\mathrm{v} / \mathrm{v})$, $2 \times \mathrm{SSC}, 1 \mu \mathrm{g} / \mathrm{ul}$ of sheared herring sperm DNA (Boehringer, Mannheim West Germany), and $5 \mathrm{ng} / \mathrm{ul}$ of AAF-labelled probe DNA, or $0.25 \mathrm{ng} / \mathrm{ul} 35 \mathrm{~S}$ labelled probe DNA was applied under a coverslip. Denaturation was carried out in an oven at $80^{\circ} \mathrm{C}$ for 10 minutes. The slides were then transfered to an incubator at $37^{\circ} \mathrm{C}$ and the hybridisation was allowed to continue for at least two hours up to a maximum of 20 hours. After removal of the coverslips the slides were washed in $2 \times \mathrm{SSC} / 0.1 \% \operatorname{SDS}$ (twice for 20 minutes at room temperature), $0.1 \times \mathrm{SSC} / 0.1 \% \mathrm{SDS}$ (15 minutes at room temperature), $0 \cdot 1 \times \mathrm{SSC} / 0.1 \%$ SDS (15 minutes at $\left.60^{\circ} \mathrm{C}\right), 2 \times \mathrm{SSC} / 0 \cdot 1 \% \operatorname{SDS}(20$ minutes at room temperature) and for five minutes in phosphate buffered saline (PBS). As homology between JC virus DNA and the genomes of SV40 and BKV is reported to be $69 \%$ and $75 \%$, respectively, ${ }^{29}$ only JC virus hybrids were expected to be stable at the standard washing conditions used. To test this the stringency of washing was varied. After hybridisation with either JCV, SV40, or BKV probes, for the stringent wash, sections of PML tissue were treated with $2 \times \mathrm{SSC} / 0.1 \% \mathrm{SDS}$ for 15 minutes at room temperature, or $0.1 \times \mathrm{SSC} / 0.1 \% \mathrm{SDS}$ for 15 minutes at room temperature, or at $40^{\circ} \mathrm{C}$, or $60^{\circ} \mathrm{C}$, or $68^{\circ} \mathrm{C}$.

For immunocytochemical detection of hybrids, the slides were preincubated with $2 \%$ bovine serum albumin (BSA) in PBS for 30 minutes at room temperature and dehydrated. Detection of the AAFlabelled, in situ hybridised probe was performed by incubation of monoclonal anti-AAF antibody (1500, kindly provided by Dr RA Baan, Rijswijk, The Netherlands) for 45 minutes at $37^{\circ} \mathrm{C}$ in $\mathrm{PBS} / 0.05 \%$ Tween-20, three washes with PBS/Tween-20, incubation with peroxidase conjugated rabbit anti-mouse Ig, and peroxidase staining for two to 10 minutes with $0.05 \%$ diamine benzidine/0.05\% $\quad \mathrm{H}_{2} \mathrm{O}_{2} / 0.01 \quad \mathrm{M}$ Imidazole. The slides were washed with PBS and distilled water, dehydrated, counterstained with Mayer's haematoxylin and embedded in paraffin wax. For autoradiography the slides were dipped in Kodak emulsion NBT2 at $50^{\circ} \mathrm{C}$ and exposed for between six 
and 12 hours at $4^{\circ} \mathrm{C}$. The slides were developed with Kodak D19 developer for five minutes, washed in distilled water, and fixed in 10\% Agefix (AGFAGevaert, Leverkusen, West Germany) for five minutes.

For combined GFAP staining and in situ hybridisation, GFAP immunocytochemistry was performed before in situ hybridisation.

\section{IMMUNOCYTOCHEMICAL GFAP STAINING}

GFAP labelling was used to identify astrocytes. The immunoperoxidase staining was done as described above with polyclonal rabbit anti-GFAP (1/50, Eurodiagnostics, Apeldoorn, The Netherlands) for 45 minutes at $37^{\circ} \mathrm{C}$ and peroxidase conjugated goat antirabbit $\operatorname{Ig}\left(1 / 100\right.$ Sanbio) for 45 minutes at $37^{\circ} \mathrm{C}$.

\section{DOT AND SOUTHERN HYBRIDISATION}

Filter hybridisation

Isolated DNA was denatured for five minutes at $100^{\circ} \mathrm{C}$, quenched on ice, and a volume of $1 \mu \mathrm{l}$ was spotted on nitrocellulose filters (Sartorius) previously wetted in $2 \times$ SSC. Total human DNA was used as a negative control and cloned JC virus DNA as a positive control. The filter was air dried and baked for two hours at $80^{\circ} \mathrm{C}$. Non-radioactive filter hybridisation was performed by preincubating the filters with $3 \times$ SSC, $0 \cdot 1 \%$ polyvinyl pyeolidon (PVP)/Ficoll, $0.2 \%$ BSA, and $500 \mu \mathrm{g} / \mathrm{ml}$ sheared herring sperm DNA for one hour at $60^{\circ} \mathrm{C}$ and incubation with $3 \times$ SSC, 0.02\% PVP/Ficoll, 0.04\% BSA, 5\% dextran sulphate and $300 \mu \mathrm{g} / \mathrm{ml}$ sheared herring sperm DNA for 30 minutes at $60^{\circ} \mathrm{C}$. The AAF-modified probe was denatured for four minutes at $100^{\circ} \mathrm{C}$, quenched on ice, and added to a final concentration of $250 \mathrm{ng} / \mathrm{ml}$. Overnight hybridisation was carried out at $60^{\circ} \mathrm{C}$ with continuous shaking. The filters were washed three times with $2 \times \mathrm{SSC}$ at $60^{\circ} \mathrm{C}$ for 15 minutes, twice with $1 \times \mathrm{SSC}$ at $60^{\circ} \mathrm{C}$ for five minutes, twice with $0.3 \times \mathrm{SSC}$ at $60^{\circ} \mathrm{C}$ for five minutes, once with $0.1 \times \mathrm{SSC}$ at $60^{\circ} \mathrm{C}$ for five minutes, once with $-2 \times \mathrm{SSC}$ at room temperature and dried on filter paper. Immunoenzymic detection was carried out by preincubating the filters with $1 \%$ PVP/Ficoll, $1 \%$ BSA

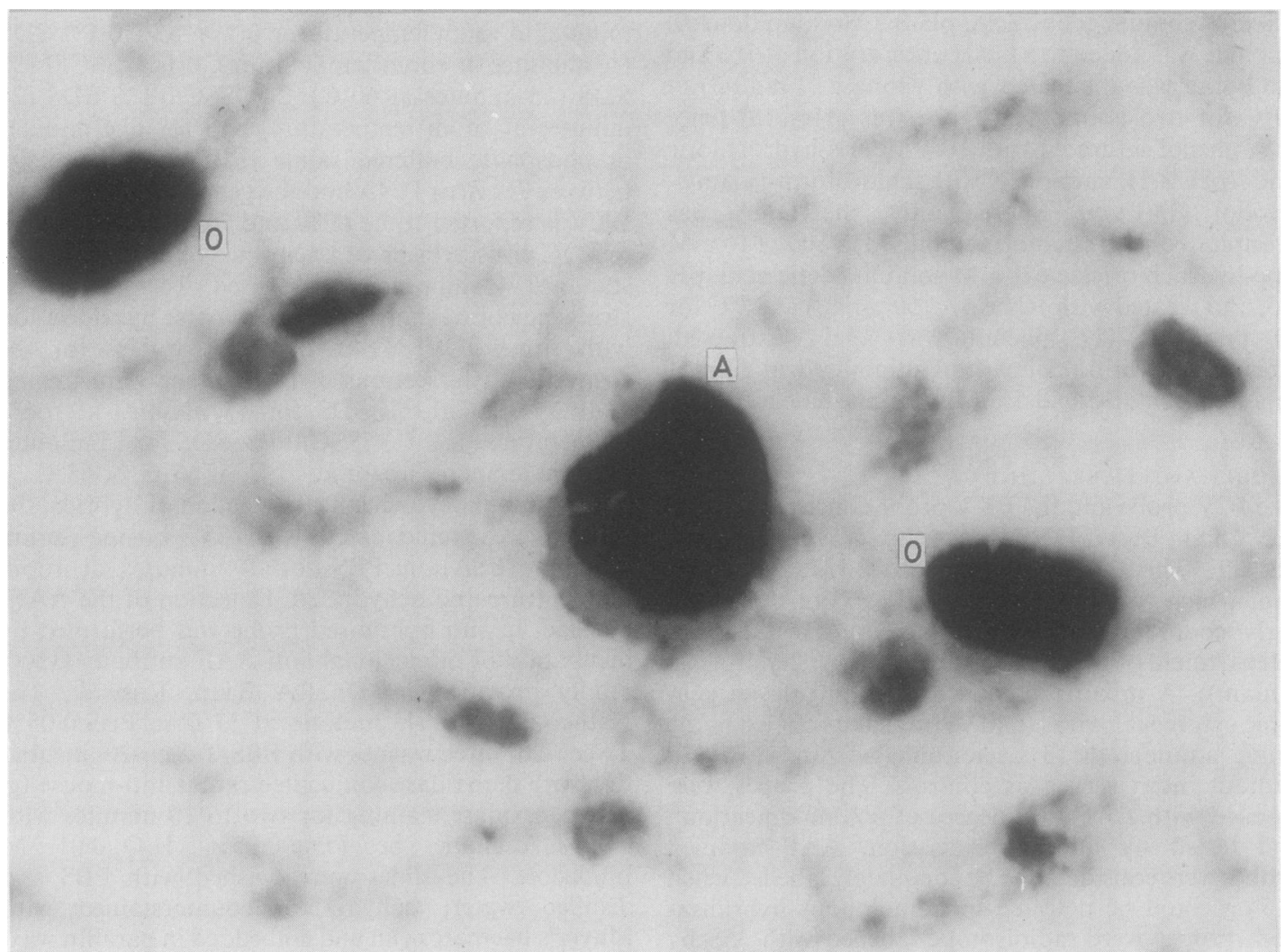

Fig 2 In situ hybridisation with AAF labelled probe to brain tissue of case 1 showing very intense staining of nuclei of oligodendrocytes $(O)$ and transformed astrocyte $(A)$. 


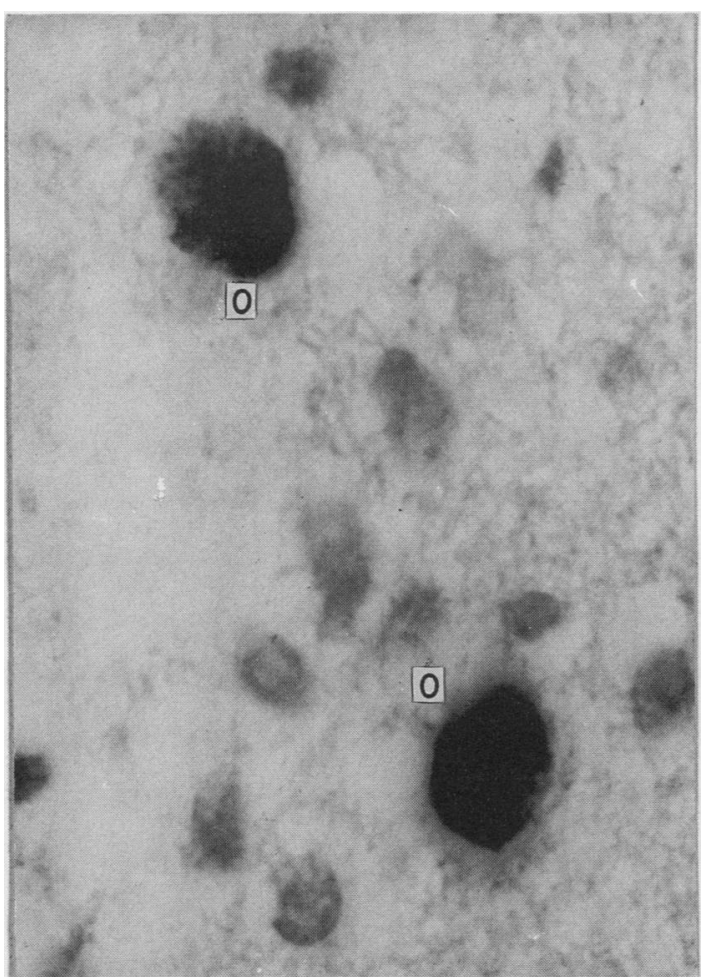

Fig 3 In situ hybridisation on biopsy specimen of case 2. Two infected oligodendrocytes $(O)$ are stained.

(Haematoxylin counterstain.)

in PBS for 30 minutes at room temperature, drying, and baking for 15 minutes at $80^{\circ} \mathrm{C}$. Subsequently the filters were incubated with a monoclonal mouse-antiAAF diluted 2000 times in $2 \%$ BSA in PBS and alkaline phosphatase goat-anti-mouse antibody (diluted 500 times in $2 \%$ BSA in PBS). Visualisation was carried out by incubating the filter with a substrate solution containing $0.33 \mathrm{mg} / \mathrm{ml}$ Nitro Blue Tetrazolium (NBT) and $0 \cdot 16 / \mathrm{ml} 5$-bromo-4-chloro-3indolyl-phosphate (BCIP) in $0.2 \mathrm{M}$ Tris-hydrochloric acid, $10 \mathrm{mM} \mathrm{MgCl2}$, pH 9. For Southern blot hybridisation, endonucleases (HindIII and EcoRI, Promega Biotec, Leiden, The Netherlands) were used according to the manufacturer's instructions. AAFlabelled phage III lambda DNA cut with HindIII and EcoRI was used as the molecular weight marker. DNA (400 ng) isolated from brain tissue was incubated with 10-20 U of enzyme for two hours at $37^{\circ} \mathrm{C}$. Total human DNA and cloned JC virus DNA were used as controls. Electrophoresis was performed using horizontal agarose slab gels at 1.7 volts $/ \mathrm{cm}$ for 16 hours in a Tris-borate buffer $(0.089 \mathrm{M}$ Tris-borate, $0.089 \mathrm{M}$ boric acid, $2 \mathrm{mM}$ edetic acid, $\mathrm{pH} \mathrm{8.0)}$ ) containing $0.5 \mu \mathrm{g} / \mathrm{ml}$ ethidium bromide. DNA bands were visualised under ultraviolet light and transferred to

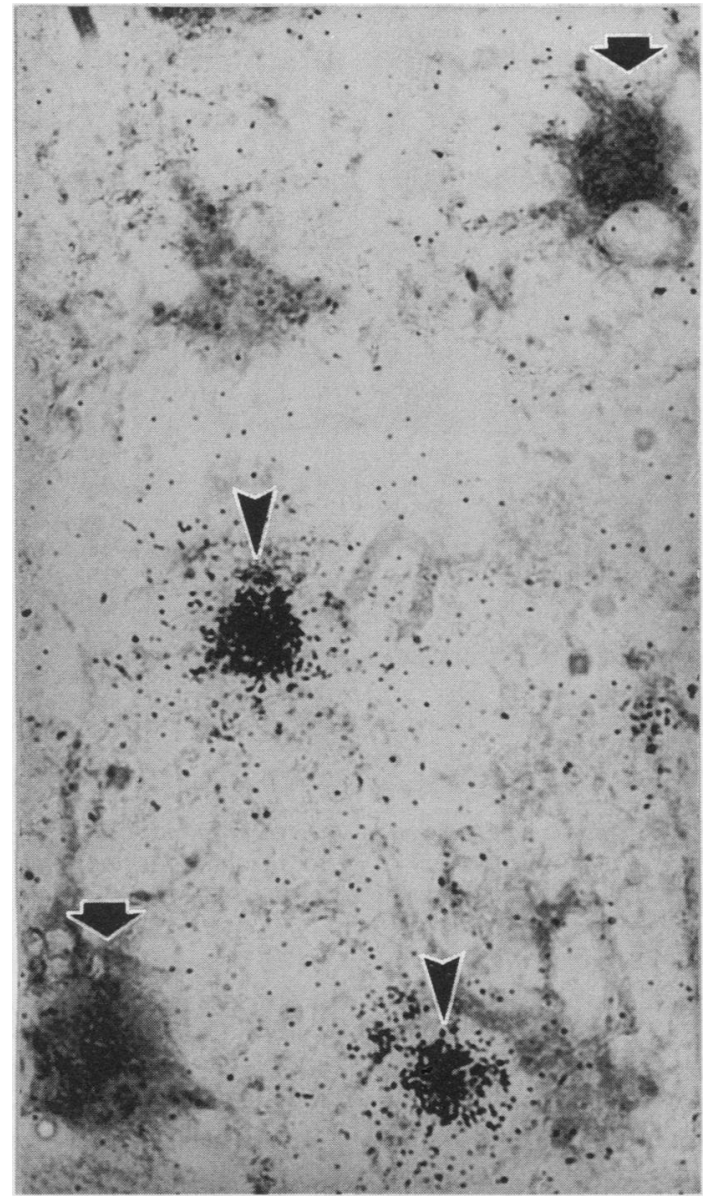

Fig 4 GFAP-immunoperoxidase staining of brain tissue from case 2 combined with $35 S-J C V-D N A$ in situ hybridisation. Arrows indicate GFAP-positive cells, arrowheads indicate 35S-JCV-DNA in situ hybridisation signal.

nitrocellulose filters (Sartorius) for hybridisation. ${ }^{30}$ Hybridisation and subsequent immunoenzymic visualisation were carried out as described above.

\section{Results}

\section{IN SITU HYBRIDISATION}

Necropsy tissue from case 1 showed many cells (about $30 \%$ ) diffusely scattered through the tissue and strongly positive with both AAF and 35S-labelled JCVDNA probes. Hybridisation with SV40 DNA produced no specific in situ hybridisation signal after the standard wash $\left(0.1 \times \mathrm{SSC} / 0.1 \% \mathrm{SDS}\right.$ at $\left.60^{\circ} \mathrm{C}\right)$, and with the BKV probe only a very faint signal was observable. Reducing the stringency of the washes to $0 \cdot 1 \times \mathrm{SSC} / 0 \cdot 1 \% \mathrm{SDS}$ at $40^{\circ} \mathrm{C}$ or $2 \times \mathrm{SSC} / 0.1 \% \mathrm{SDS}$ at room temperature resulted in slightly increased 


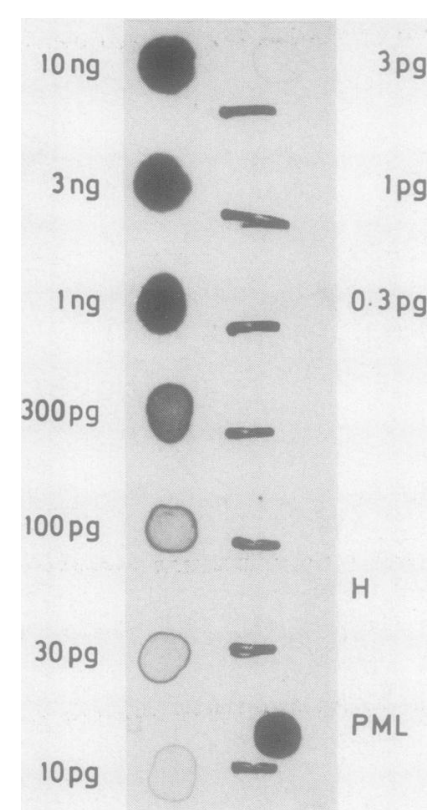

Fig 5 Case 1: non-radioactive dot-hybridisation. 1 to 12: three-fold dilution series of JCV-DNA from $100 \mathrm{ng}$ to $0.3 \mathrm{pg}$; $P M L: 50 \mathrm{ng}$ of DNA isolated from brain: $\mathrm{H}: 600 \mathrm{ng}$ total human DNA (negative control).

signals for the BKV hybridisation, but the intensity remained far below those of JCV-DNA hybridisations. SV40 hybridisations remained at background level at reduced stringency. Increasing the wash stringency to $0.1 \times \mathrm{SSC} / 0.1 \% \mathrm{SDS}$ at $68^{\circ} \mathrm{C}$ resulted in complete loss of BKV signal; the JCV signal was still present at somewhat lower intensity. No differences were observed between $35 \mathrm{~S}$ and AAF experiments regarding the number of positive cells. Control CMV and pBR322 probes gave negative results. With the AAF labelled JCV-DNA probe the nuclei stained dark brown with sometimes a light staining of the cytoplasm. Due to loss of morphological detail caused by autolysis of this tissue before fixation, irrefutable typing of stained cells was not possible. Nevertheless, most infected cells seemed to be oligodendrocytes, but occasionally astrocytes were also stained. In some instances we observed perivascular groups of large cells which seemed to be transformed. The unstained cells were identified as normal oligodendrocytes, endothelial cells, neurons and occasionally macrophages. No staining of leucocytes was observed. ${ }^{31}$

Only with the JCV-DNA probe did the biopsy tissue from case 2 show intense staining of a few cells (less than $1 \%$ ) in the only area of obvious histopathological change at the edge of the biopsy specimen (fig 3). Some plasma cells were present in the lesion. The focus was surrounded by apparently normal tissue. Again the

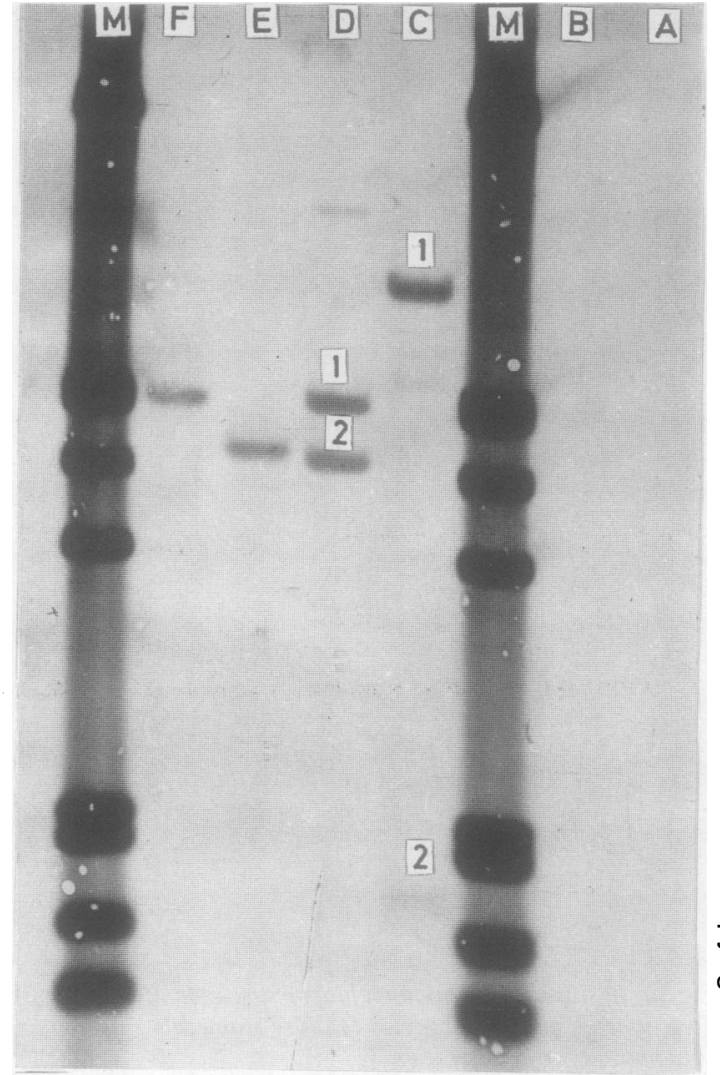

Fig 6 Case 1: non radioactive Southern blot hybridisation. Lane A: total human DNA cut with HindIII; lane B: as A cut with EcoRI; lane M: AAF labelled molecular weight markers; lane C: JCV-DNA cloned into pBR322 cut with HindIII: 1: pBR322 + HindIII-A fragment of JCV genome, 2: HindIII-B fragment of JCV genome; lane D: as $C$ cut with EcoRI: 1: JCV genome, 2: pBR322; lane E: DNA isolated from brain cut with HindIII; lane F: as Ecut with EcoRI.

AAF signal was almost totally confined to the nuclei with some very light staining of the cytoplasm. These cells seemed to be enlarged oligodendrocytes. Neither bizarre, changed astrocytes, nor signs of demyelination were observed. Again, we did not observe staining of neurons or endothelial cells in either of the examined tissues.

To confirm the morphological observation that the principal infected cell type was the oligodendrocyte and not the astrocyte, GFAP immunostaining, which labels astrocytes, ${ }^{32}$ was combined with $35 \mathrm{~S}$ in situ hybridisation. Fig 4 shows that no GFAP positive cells were infected.

DOT AND SOUTHERN BLOT HYBRIDISATION

The intensity of the signals obtained with non-radioactive dot hybridisation on DNA isolated from brain 
tissue of case 1 shows more than 1 ng JCV-DNA/mg brain DNA (fig 5). This finding accords with the results of radioactive dot hybridisation ${ }^{13}$ and is equivalent to about 5000 viral copies per diploid amount of DNA. If combined with in situ hybridisation, this means that there were about 15000 copies for every infected cell in case 1 . In case 2 the disease process was localised more focally, exemplified by the localisation of histopathological changes at the edge of the biopsy specimen. A comparison of in situ and filter hybridisation was therefore meaningless in this patient. No cross hybridisation with human DNA was observed.

Southern blot hybridisation (fig 6) shows specific hybridisation with JCV-DNA present in DNA isolates from case 1 and with both pBR322- and JCV-sequences present in probe DNA. Again, no cross hybridisation with human or salmon sperm DNA was observed. The genome size of the patients' JC virus was determined to be 5000 base pairs by reference to the cloned JC virus DNA and phase $\lambda$ markers. This size is compatible with results published earlier ${ }^{29}$ Comparison with restriction maps ${ }^{33}$ showed that cleavage sites for HindIII $(4498,4914,5112)$ and EcoRI (1722) in JCV-DNA were consistent with standard map sites. ${ }^{334}$ As the amount of DNA representing the fragments HindIII-B and $-C$ is too small to permit detection, the total length of JCV-DNA fragments obtained with this enzyme seems to be somewhat smaller than 5 kilobase pairs. The intensity of the signal suggests about $4 \mathrm{ng}$ JCV-DNA/100 ng total DNA, which is compatible with the intensity of signal obtained with dot hybridisation.

\section{Discussion}

The results clearly indicate that $\mathrm{JCV}$, and not $\mathrm{BKV}$, or SV40 was the aetiological agent for PML in the patients studied. With in situ hybridisation very intense staining was seen in nuclei, compatible with the intranuclear replication of JC virus. Most of the infected cells were glial. As evidenced from the combined immunoperoxidase GFAP staining and 35S in situ hybridisation, these glia seem to be oligodendrocytes. These findings agree with those previously published on the use of in situ hybridisation in PML. ${ }^{20-23}$ We did not find morphological evidence of endothelial or neuronal infection as reported by Dorries et al ${ }^{19}$ and Nakamura et al. ${ }^{22} 23$

The observed difference in percentage of infected cells between material from the two patients is probably a reflection of the clinical stage of the disease, the process being more diffuse and extensive in case 1 .

The results obtained on material from case 2 provide an example of the usefulness of non-radio- active in situ hybridisation for the diagnosis of PML before death. It also shows the power of this technique in combining structural and biochemical information. Furthermore, it permits relatively easy and fast detection of only a few infected cells in a small biopsy sample.

The clinical course of case 2 is remarkable as he remained in a stable and relatively good condition until 12 months after onset of disease. Perhaps the plasma cells seen in the biopsy specimen from this patient can be interpreted as an immune response mounted against the virus. ${ }^{3}$ Furthermore, antiviral treatment may have influenced the disease, as has been reported elsewhere. ${ }^{73536}$

The intensities of $\mathrm{JC}$ virus specific signals obtained with filter hybridisation are similar to those obtained with in situ hybridisation. The number of viral copies per infected cell correlated with the findings of $\mathrm{ZuR}$ hein and Chou, ${ }^{37} \mathrm{ZuRhein},{ }^{38}$ and Dorries. ${ }^{19}$

The combined quantitation and localisation of JC virus in single cells is important for studying the pathogenesis of PML, which could be the result of reactivation of a latent virus in an immune compromised patient. ${ }^{4}$ Although evidence of the presence of latest JC virus in other organs is available ${ }^{3139-42}$ and excretion in the urine has been found, ${ }^{43-46}$ the clinical importance of these findings is not clear. Hybridisation techniques can be used to scan the body for the presence of viral DNA ${ }^{40}$ and to pinpoint the virus to certain cell types. Investigation of $\mathrm{JC}$ virus isolates with restriction enzymes also suggests that these subtypes circulate, with some heterogeneity of DNA isolated from different organs. ${ }^{404247}$ As shown by the Southern filter hybridised with AAF labelled probe, problems concerning the molecular epidemiology of JC virus can be studied using non-radioactive hybridisation techniques. Research of various aspects of JC virus is important as it may have other effects as exemplified by the study of the oncogenic potential of JC virus in experimental animals. ${ }^{48}$

The detection of polyomavirus using AAF labelled probes can be used to establish rapidly the diagnosis of PML both in biopsy and necropsy material. The disease might become treatable if more effective antiviral drugs are developed. Therefore the application of in situ hybridisation for rapid, early diagnosis of PML in brain tissue is strongly recommended.

This study was supported in part by the "Stichting Prof AAH Kassenaar Fonds" at the Medical Faculty of the University of Leiden, The Netherlands.

We thank P H L Kessing for providing the MRI-scan results and Professor G H A M Bots for providing morphological data. 


\section{References}

1 Astrom KE, Mancall EL, Richardson EP. Progressive multifocal leucoencephalopathy. Brain 1958;81:93-110.

2 Padgett BL, Walker DL, ZuRhein GM, et al. Cultivation of papova-like virus from human brain with progressive multifocal leucoencephalopathy. Lancet 1971;i:1257-60.

3 Walker DL. Progressive multifocal leukoencephalopathy: an opportunistic viral infection of the central nervous system. In: Vinken PJ, Bruyn GW, eds. Handbook of clinical neurology. Vol 34. Infections of the nervous system. Amsterdam: NorthHolland Publishing Co, 1978:307-29.

4 Walker DL. Progressive multifocal leukoencephalopathy. In Koetsier JC, ed. Handbook of clinical neurology Vol 3. Demyelinating diseases. Amsterdam: Elsevier, 1985:1503-24.

5 Weiner LP, Herndon RM, Narayan O, et al. Isolation of virus related to SV40 from patients with progressive multifocal leukoencephalopathy. $N$ Engl J Med 1972;286:385-90.

6 Scherneck S, Geissler E, Janisch W, et al. Isolation of a SV40-like virus from a patient with progressive multifocal leukoencephalopathy. Acta Virol 1981;25:191-8.

7 Peters ACB, Versteeg J, Bots GTAM, et al. Progressive multifocal leukoencephalopathy. Immunofluorescent demonstration of simian virus $\mathbf{4 0}$ antigen in CSF cells and response to cytarabine therapy. Arch Neurol 1980;37:497-501.

8 Hayashi T, Sumiyoshi A, Tanaka M, et al. Progressive multifocal leucoencephalopathy. A case report with special reference to SV40 etiology. Acta Pathol Jpn 1985;35:173-8.

9 Sever JL. Polyomaviruses and human neurologic disease: major advances in 25 years. In: Sever JL, Madden DL, eds. Polyomaviruses and human neurological disease. New York: Alan R Liss, 1983:179-83.

10 Bedri J, Weinstein W, DeGregorio P, Veriry MA. Progressive multifocal leukoencephalopathy in acquired immunodeficiency syndrome. N Engl J Med 1985;309:492-3.

11 Blum LW, Chambers RA, Schwartzman J, et al. Progressive multifocal leukoencephalopathy in acquired immune deficiency syndrome. Arch Neurol 1985;42:137-9.

12 Ho JL, Poldre PA, McEniry D, et al. Acquired immunodeficiency syndrome with progressive multifocal leukoencephalopathy and monoclonal B-cell proliferation. Ann Intern Med 1984;100:693-6.

13 Speelman JD, ter Schegget J, Bots GThAM, et al. Progressive multifocal leukoencephalopathy in a case of immune deficiency syndrome. Clin Neurol Neurosurg 1985;87:27-32.

14 Miller JR, Barrett RE, Britton CB, et al. Progressive multifocal leukoencephalopathy in a male homosexual with T-cell immune deficiency. $N$ Engl J Med 1982;307:1436-7.

15 Stoner GL, Ryschkewitsch CF, Walker DL, et al. JC papovavirus large tumour (T)-antigen expression in brain tissue of AIDS and non-AIDS patients with progressive multifocal leucoencephalopathy. Proc Natl Acad Sci USA 1986;83:2271-5.

16 Gerber MA, Shah KV, Thung SN, et al. Immunohistochemical demonstration of common antigen of polyomaviruses in routine histological tissue sections of animal and man. Am J Clin Pathol 1980;6:794-7.

17 Budka H, Shah KV. Papovavirus antigens in paraffin sections of PML brains. In: Sever JL, Madden DL, eds: Polyomaviruses and human neurological diseases. New York: Alan R Liss, 1983: 299-311.

18 Greenlee JE, Keeney PM. Immunoenzymatic labelling of JC papovavirus $T$ antigen in brains of patients with progressive multifocal leukoencephalopathy. Acta Neuropathol 1986; 71:150-3.

19 Dorries K, Johnson RT, ter Meulen V. Detection of polyoma virus DNA in PML-brain tissue by (in situ) hybridization. J Gen Virol 1979;42:49-57.

20 Aksamit AJ, Mourrain P, Sever JL, et al. Progressive multifocal leukoencephalopathy: investigation of three cases using in situ hybridization with JC virus biotinylated DNA probe. Ann
Neurol 1985;18:490-6.

21 Aksamit AJ, Sever JL, Major EO. Progressive multifocal leukoencephalopathy: JC virus detection by in situ hybridization compared with immunohistochemistry. Neurology (NY) 1986;36:499-504.

22 Nakamura S, Tourtelotte WW, Shapshak P, et al. The detection of papovavirus nucleotide sequences in cortical neurons of a patient with progressive multifocal leukoencephalopathy (PML) by in situ hybridization. Rinsho Shikeigaku 1985;25:1148-51.

23 Nakamura S, Tourtelotte WW, Shapshak P, et al. Patient with progressive multifocal leukoencephalopathy by in situ hybridization comparison of in situ hybridization using isotopic and biotinylated probes. No To Shinkei 1985;37:359-64.

24 Shapshak P, Tourtelotte WW, Wolman M, et al. Search for virus nucleic acid sequences in postmortem human brain tissue using in situ hybridization technology with cloned probes: some solutions and results on progressive multifocal leukoencephalopathy and subacute sclerosing panencephalitis tissue. $J$ Neurosci Res 1986;16:281-301.

25 Raap AK, Geelen JL, van der Meer JWM, et al. Non-radioactive in situ hybridization for the detection of cytomegalovirus infections. Histochemistry 1988;88:367-73.

26 Landegent JE, Jansen in de Wal N, Baan RA, et al. 2Acetylamino- fluorene-modified probes for the indirect hybridocytochemical detection of specific nucleic acid sequences. Exp Cell Res 1984;153:61-72.

27 Rigby PWJ, Dieckman M, Rhodes C, Berg P. Labelling deoxynucleic acid to high specific activity in vitro by nicktranslation with DNA polymerase I. J Mol Biol 1977;113:237.

28 Burns J, Redfern DRM, Esiri MM, McGee JO'D. Human and viral gene detection in routine paraffin embedded tissue by in situ hybridization with biotinylated probes: viral localisation in herpes encephalitis. J Clin Pathol 1986;39:1066-73.

29 Frisque RJ, Bream GL, Canella MT. Human polyoma virus JC virus genome. J Virol 1984;51:458-69.

30 Southern E. Detection of specific sequences among DNA fragments separated by gel electrophoresis. J Mol Biol 1975;98:503.

31 Houff SA, Major EO, Katz DA, et al. Involvement of JC-virus infected mononuclear cells from the bone marrow and spleen in the pathogenesis of progressive multifocal leukoencephalopathy. N Engl J Med 1987;318:301-5.

32 Eng LF, DeArmond SJ. Immunochemistry of the glial fibrillary acidic protein. In: Zimmerman HM, ed. Progress in neuropathology. Vol 5. New York: Raven Press, 1983:19-41.

33 Martin JD, Frisque RJ, Padgett BL, et al. Restriction endonuclease cleavage map of the DNA of JC virus. $J$ Virol 1979;29:846-55.

34 Grinnell BW, Padgett BL, Walker DL. Comparison of infectious JC virus DNAs cloned from human brain. J Virol 1983;45: 299-308.

35 Bauer WR, Turel AP, Johnsson KP. Progressive multifocal leukoencephalopathy and cytarabine. JAMA 1973;226:174-6.

36 Marriot PJ, O'Brien MD, Mackenzie ICK, et al. Progressive multifocal leukoencephalopathy: remission with cytarabine. $J$ Neurol Neurosurg Psychiatry 1975;38:205-9.

$37 \mathrm{ZuRhein} \mathrm{GM,} \mathrm{Chou} \mathrm{S-M.} \mathrm{Papovavirus} \mathrm{in} \mathrm{progressive} \mathrm{multifocal}$ leukoencephalopathy. Res Publ Assoc Nerv Ment Dis $1968 ; 44: 307-62$.

$38 \mathrm{ZuRhein}$ GM. Association of papova-virions with a human demyelinating disease (progressive multifocal leukoencephalopathy). Prog Med Virol 1969;11:185-247.

39 McCance DJ. Persistence of animal and human papovaviruses in renal and nervous tissues. In: Sever JL, Madden DL, eds. Polyomaviruses and human neurological disease. New York: Alan R Liss, 1983.

40 Grinnell BW, Padgett BL, Walker DL. Distribution of nonintegrated DNA from JC papovavirus in organs of patients with progressive multifocal leukoencephalopathy. J Infect Dis 1983; 147:669-75. 
41 Chesters PM, Heritage J, McCance DJ. Persistance of DNA sequences of BK virus and $\mathrm{JC}$ virus in normal human tissues and in diseased tissues. J Infect Dis 1983;147:676-84.

42 Dorries K. Progressive multifocal leukoencephalopathy: analysis of JC virus DNA from brain and kidney tissue. Virol Res 1984;1:25-38.

43 Coleman DV, Wolfendale MR, Daniel RA, et al. A prospective study of human polyomavirus infection in pregnancy. $J$ Infect Dis 1980;142:1-8.

44 Hogan TF, Borden EC, McBain JA, et al. Human polyomavirus infections with JC virus and BK virus in renal transplant patients. Ann Intern Med 1980;92:373-8.

45 Beckmann AM, Shah KV, Padgett BL. Propagation and primary isolation of papovavirus $\mathrm{JC}$ in epithelial cells derived from human urine. Infect Immun 1982;38:774-7.

46 Rand KH, Johnson KP, Rubinstein LJ, et al. Adenine Arabin- oside in the treatment of progressive multifocal leucoencephalopathy: Use of virus containing cells in the urine to assess response to therapy. Ann Neurol 1977;1:458-62.

47 Martin JD, King DM, Slauch JM, et al. Differences in regulatory sequences of naturally occurring JC virus variants. $J$ Virol 1985;53:306-11.

48 ZuRhein GM. Studies of JC-virus induced nervous system tumors in the Syrian hamster: a review. In: Sever JL, Madden DL, eds. Polyomaviruses and human neurological diseases. New York: Alan R Liss, 1983;205-21.

Requests for reprints to: Dr R H Boerman, Department of Neurology, University Hospital Leiden, PO Box 9600, 2300 RC Leiden, The Netherlands. 
exposure to alkylating agents of different origin, from dietary to occupational, to medicinal. Details on all the currently available techniques for the detection of DNA adducts are given, and it is interesting and encouraging to see that, since the last meeting in 1983, progress has been made in the application of such techniques to the measurement of DNA damage in human populations, as reported by several authors.

Limited space, however, is devoted to epidemiological studies and only a few chapters discuss the link between DNA adduct detection and risk assessment. Furthermore, the absence of reports on strategies of cancer prevention was most disappointing. It would have been of great interest, as anticipated in the title, to learn how the existing techniques could be applied to the prevention of some environmental cancers.

Despite these shortcomings, the book offers comprehensive and updated information on the latest achievements in molecular dosimetry studies and provides some useful reading to scientists involved in this field of research.

ANNA MARIA BEDFORD

Tumor Progression and Metastasis. UCLA Symposia on Molecular and Cellular Biology. New Series. Vol. 78. Ed GL Nicolson, IJ Fidler. (Pp 322; \$140.00.) Alan R Liss Inc. 1988. ISBN 0-8451-2677-6.

Altered Glycosylation in Tumor Cells. UCLA Symposia on Molecular and Cellular Biology. New Series. Vol. 79. Ed CL Reading, S Hakomori, DM Marcus. (Pp 350; $\$ 140.00$.) Alan $R$ Liss Inc. 1988. ISBN 08451- 2678-4.

These books contain papers of varying length and quality that represent the proceedings of UCLA symposia held in Keystone, Colorado in April 1988. Professor Robin Weiss has recently reviewed the proceedings of a UCLA symposium published in the same series ( $J$ Clin Pathol 1988;41:1139-1140) and we echo his doubts over the value of such publications. It is claimed that Volume 78 "thoroughly reviews the pathogenesis of metastasis and the unique properties of highly malignant cells and their microenvironment" and that Volume 79 "comprehensively explores the underlying regulation of altered glycosyla- tion after oncogenic transformation and the functional significance of these changes". As suggested by Professor Weiss, it is highly likely that the meetings were useful forums for the exchange of new data and views, but the books, although well presented, do not live up to these rather ambitious claims. Some papers in both books describe interesting and well performed studies. But many contain preliminary data or, in some cases, brief reviews of the work of a particular laboratory. In some cases the latter is little more than ex cathedra statement with little reference to the work of other groups.

Of particular concern is the fact that 126 pages $(39.1 \%)$ of Volume 78 and 205 pages $(58.6 \%)$ of Volume 79 have been published in the Journal of Cellular Biochemistry (Alan $R$ Liss Inc) in exactly the same format. Indeed, in both volumes these pages are paginated twice, once for the book and once with the journal page numbers. These books each cost \$140, and since, in general, the useful papers were the ones that have previously appeared in the Journal of Cellular Biochemistry, we find it difficult to imagine who would buy them. Perhaps they are purchased by individuals and libraries who are unaware of the double publication. Is it right that such blatant double publication occurs? Perhaps the editors and readers of the J Clin Pathol might like to comment?

STELLA KEEBLE

\section{Some new titles}

The receipt of books is acknowledged, and this listing must be regarded as sufficient return for the courtesy of the sender. Books that appear to be of particular interest will be reviewed as space permits.

Cases in Chemical Pathology. A Diagnostic Approach. 2nd ed. RN Walmsley, LR Watkinson, ESC Koay. (Pp 365; A\$40.00.) The Australian Association of Clinical Biochemists. 1988. ISBN 981-3096-05-5.

The Clinical Chemistry of Laboratory Animals. Eds WF Loeb, FW Quimby. (Pp 519; £38.50.) Pergamon Press. 1988. ISBN 0080351808 .

Vertebral Malformations. K Theiler. Advances in Anatomy Embryology and Cell Biology. (Pp 99; 145 figs.; soft cover DM 98.00.) Springer. 1989. ISBN 3-540-19359-6.

\section{Corrections}

Dr JW Keyser's authorship was omitted from the book Human Plasma Proteins, a review of which was published in this Journal.

In the summary of the paper, Diagnosis of progress in multifocal leucoencephalopathy by hybridisation techniques, the studied material from the second patient was incorrectly stated as being from a necropsy specimen: it was, in fact, obtained from a brain biopsy specimen. ( $J$ Clin Pathol 1989;42:153-61.)

Authorship of the paper, Lupus anticoagulant, anticardiolipin antibodies and human immunodeficiency virus in haemophilia was wrongly attributed to GF Savage; it should have been attributed to GF Savidge. (J Clin Pathol 1989;42:629-33.) 
exposure to alkylating agents of different origin, from dietary to occupational, to medicinal. Details on all the currently available techniques for the detection of DNA adducts are given, and it is interesting and encouraging to see that, since the last meeting in 1983, progress has been made in the application of such techniques to the measurement of DNA damage in human populations, as reported by several authors.

Limited space, however, is devoted to epidemiological studies and only a few chapters discuss the link between DNA adduct detection and risk assessment. Furthermore, the absence of reports on strategies of cancer prevention was most disappointing. It would have been of great interest, as anticipated in the title, to learn how the existing techniques could be applied to the prevention of some environmental cancers.

Despite these shortcomings, the book offers comprehensive and updated information on the latest achievements in molecular dosimetry studies and provides some useful reading to scientists involved in this field of research.

ANNA MARIA BEDFORD

Tumor Progression and Metastasis. UCLA Symposia on Molecular and Cellular Biology. New Series. Vol. 78. Ed GL Nicolson, IJ Fidler. (Pp 322; \$140.00.) Alan R Liss Inc. 1988. ISBN 0-8451-2677-6.

Altered Glycosylation in Tumor Cells. UCLA Symposia on Molecular and Cellular Biology. New Series. Vol. 79. Ed CL Reading, S Hakomori, DM Marcus. (Pp 350; $\$ 140.00$.) Alan $R$ Liss Inc. 1988. ISBN 08451- 2678-4.

These books contain papers of varying length and quality that represent the proceedings of UCLA symposia held in Keystone, Colorado in April 1988. Professor Robin Weiss has recently reviewed the proceedings of a UCLA symposium published in the same series ( $J$ Clin Pathol 1988;41:1139-1140) and we echo his doubts over the value of such publications. It is claimed that Volume 78 "thoroughly reviews the pathogenesis of metastasis and the unique properties of highly malignant cells and their microenvironment" and that Volume 79 "comprehensively explores the underlying regulation of altered glycosyla- tion after oncogenic transformation and the functional significance of these changes". As suggested by Professor Weiss, it is highly likely that the meetings were useful forums for the exchange of new data and views, but the books, although well presented, do not live up to these rather ambitious claims. Some papers in both books describe interesting and well performed studies. But many contain preliminary data or, in some cases, brief reviews of the work of a particular laboratory. In some cases the latter is little more than ex cathedra statement with little reference to the work of other groups.

Of particular concern is the fact that 126 pages $(39.1 \%)$ of Volume 78 and 205 pages $(58.6 \%)$ of Volume 79 have been published in the Journal of Cellular Biochemistry (Alan $R$ Liss Inc) in exactly the same format. Indeed, in both volumes these pages are paginated twice, once for the book and once with the journal page numbers. These books each cost \$140, and since, in general, the useful papers were the ones that have previously appeared in the Journal of Cellular Biochemistry, we find it difficult to imagine who would buy them. Perhaps they are purchased by individuals and libraries who are unaware of the double publication. Is it right that such blatant double publication occurs? Perhaps the editors and readers of the J Clin Pathol might like to comment?

STELLA KEEBLE

\section{Some new titles}

The receipt of books is acknowledged, and this listing must be regarded as sufficient return for the courtesy of the sender. Books that appear to be of particular interest will be reviewed as space permits.

Cases in Chemical Pathology. A Diagnostic Approach. 2nd ed. RN Walmsley, LR Watkinson, ESC Koay. (Pp 365; A\$40.00.) The Australian Association of Clinical Biochemists. 1988. ISBN 981-3096-05-5.

The Clinical Chemistry of Laboratory Animals. Eds WF Loeb, FW Quimby. (Pp 519; £38.50.) Pergamon Press. 1988. ISBN 0080351808 .

Vertebral Malformations. K Theiler. Advances in Anatomy Embryology and Cell Biology. (Pp 99; 145 figs.; soft cover DM 98.00.) Springer. 1989. ISBN 3-540-19359-6.

\section{Corrections}

Dr JW Keyser's authorship was omitted from the book Human Plasma Proteins, a review of which was published in this Journal.

In the summary of the paper, Diagnosis of progress in multifocal leucoencephalopathy by hybridisation techniques, the studied material from the second patient was incorrectly stated as being from a necropsy specimen: it was, in fact, obtained from a brain biopsy specimen. ( $J$ Clin Pathol 1989;42:153-61.)

Authorship of the paper, Lupus anticoagulant, anticardiolipin antibodies and human immunodeficiency virus in haemophilia was wrongly attributed to GF Savage; it should have been attributed to GF Savidge. (J Clin Pathol 1989;42:629-33.) 